\title{
Smoking menace still haunting humanity ${ }^{1}$
}

\author{
Rajmund Dąbrowski \\ Seventh-day Adventist Church
}

\author{
ADDRESS FOR CORRESPONDENCE: Rajmund Dąbrowski, Communication Director Rocky Mountain Conference \\ of the Seventh-day Adventist Church, e-mail: rayd@rmcsda.org
}

November 1 came and went, and you may not have noted that another win was scored on behalf of children. A new law aimed at protecting children from secondhand smoke will make it illegal to smoke in private cars that have children in them. It is one small step in the gigantic fight against one of the largest enemies of mankind: smoking.

This is not a problem for Seventh-day Adventists, who are among the world's largest communities known for their abstinence from smoking tobacco. As a faith community, Seventh-day Adventists have elected to be doctrinal about it, and for decades have been known for our breathe-free outreach around the world.

On October 27-28, I was reminded about being involved in a major nation-wide public health programme in Poland in the early 1980s - alongside Prof. Witold Zatoński, founder and president of the Health Promotion Foundation based in Poland - when the then Five-DayStop Smoking Plan $^{2}$ attracted literally thousands of smokers who flooded Adventist churches and public venues. The programme, which was re-formatted for TV, with manuals printed in daily newspapers, ignited a national debate and resulted in smoking being banned in public places.

For Seventh-day Adventists, the stance against smoking and tobacco dates back to the middle of the 1800s. This was before this Christian church was formally constituted in 1863 . As early as 1848 , the most prominent church pioneer, Ellen G. White, spoke of the harmful effects of tobacco, tea, and coffee. Adventist publications printed articles against tobacco and in 1856, another

\footnotetext{
A version of this article has appeared on 3 November 2016 on the Rocky Mountain Conference website - http://www.rmcsda.org/news_entries/6015. ${ }^{2}$ The Five-Day Plan to Stop Smoking was created by Dr. J. Wayne McFarland and Elman J. Folkenberg in 1959 and in 1962 endorsed by the church as a smoking cessation programme for pastors and health experts to offer in communities in the United States. Today, in its third generation, it is known as the Breathe-Free 2 Stop Smoking Plan. Official church statements on smoking and tobacco can be found at www.adventist.org.
}

prominent pioneer, J. N. Andrews, wrote that the use of tobacco was a "sin against God."

Explaining the health principles adhered to by Adventists, the Seventh-day Adventist Bible Encyclopaedia sums it up that Adventists "believe that Christians should have concern for health, not because of any ceremonial or legalistic significance but for the practical reason that only in a sound body can they render the most effective service to God and to others" [1]. As per a biblical statement that human bodies are "temples of the Holy Spirit" (see: $1^{\text {st }}$ Letter to Corinthians 3:16), Adventists have enshrined abstinence from tobacco, alcoholic beverages, and irresponsible use of drugs as one of the fundamental beliefs and "we are to abstain from them as well".

In more than 150 years, the church established itself as a promoter and activist for healthful living. Seventh-day Adventists in Poland recognized that its healthy-living message should be propagated from the rooftops. "Free Poland from Smoking" became a programme in which the Polish Adventist church sought to join forces with different active anti-smoking and tobacco organizations. For the church it also meant testifying that Christian witness must include practical involvement with all people whose health, and even life itself, could be spared the dangerous effects of harmful habits, as well as pointing to finding a treatment and promoting behavioural changes.

Perhaps it will be difficult to find a smoker in the world today who does not know that smoking tobacco is a "destroyer of health," causes cancer deaths, and carries numerous health hazards. This said, lecturing smokers about such dangers and making them fearful about the consequences is deemed to be obsolete.

The church continues to pin our interests on the game by also developing new approaches, which include scientific research at Loma Linda University in California, among others, making Adventist smoking cessation options current with technological advancement whilst 
maintaining that personal contacts with those who wish to quit smoking are essential in making them succeed.

A participant in national tobacco control programmes a few years ago, Dr. Mark Johnson, Public Health Executive Director, Jefferson County, Colorado, comments that, while Adventists were refining their tobacco cessation programme, "numerous other groups and organizations have developed similar [approaches] that are free of what some see as the 'taint' of religious involvement".

He says that, in addition, "new medications and other devices have expanded the armamentarium that can be used to battle the physical and emotional addiction of nicotine. While experts in the field still know of the historic role the Seventh-day Adventist Church has played in the war on tobacco, the general public is, for the most part, not aware of our activities. This can be seen either as a lost opportunity for the church, or as a natural progression in the war on tobacco, for which we should be grateful for the part we played and continue to play".

In the mid-1990s the church recognized that our faith community could also be a powerful lobbyist for tobacco control. Statements advocated for more aggressive education about the dangers of smoking, a ban on all tobacco advertising and enacting of higher tax laws on cigarettes. The church addressed the issue of ethics that are absent as profits-greedy tobacco corporations ignored the evidence of health hazards. That was then.

Twenty years later, while the picture of change is painted by enacted laws, with consumption of cigarettes down, the world community is still facing unresolved challenges, and the menace of tobacco is still present, though clothed in attractive, technologically based new-generation tobacco and nicotine products flooding the market.

It was this very issue that was behind the consultation [2] at Harvard University, October 27-28, to identify learning opportunities emerging from historical tobacco control leaders and health advocates, appraising current challenges to effective tobacco control efforts, and initiating collaboration on a roadmap for the future of tobacco control.

The meeting was convened by Professor Allan Brandt, head of Harvard's Department of the History of Science, and author of Tobacco Century: the Rise, Fall and Deadly Persistence of the Product that Defined America, to identify the new and pervasive challenge of new tobacco products, such as e-cigarettes, and their known and potential boost for the tobacco industry. As we are still learning about the health effects or dangers of e-cigarettes, "uncertainty [of effects] favors the tobacco industry", he said. It is apparent that the emergence of new technologies offers disruptive innovation to the public health status quo as technological dissemination outstrips the knowledge context. Add to this the potential of new complications, as in the next years we will be facing a completely new population with new characteristics, and new problems.
Professor Witold Zatoński, who today continues as an advocate of a smoke-free society in Poland and internationally, echoed the current and still-to-be-discovered issues in tobacco control. He said that, "supporting the treatment of tobacco/nicotine addiction is of ever growing importance in the context in which most smokers intend to quit. The correct use of existing and emerging medicines will play a decisive role in this".

"The community of anti-tobacco advocates needs to declare what goal we are striving for - a society free of combustible cigarettes, or a nicotine-free society", he added. Zatoński identifies this problem as especially pertinent with new nicotine delivery systems entering the market.

A roundtable discussion also pinpointed a need to address the role of social and religious organizations in anti-tobacco advocacy. As already mentioned, in the past decades Seventh-day Adventists have provided a robust organization platform for smoking cessation along with successful pressure on policymakers in many countries. Today's question is: What should the Adventist role be in the future when we are challenged by sophisticated and conniving approaches by the tobacco industry?

My takeout from the consultation? A voice of Christians and their active witness can add an anti-tobacco message as part of Christian pro-life, and healthy lifestyle convictions.

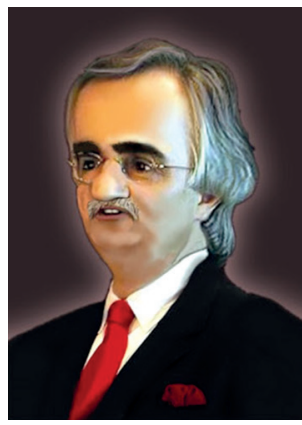

Source: Caricatures of Adventists-axaggerating the contours of adventism. Available from: http://sdacaricatures.blogspot. com/2008/09/rajmund-dabrowski.html (accessed: 15 November 2016).

Rajmund Dąbrowski, Communication Director, Rocky Mountain Conference of Seventh-day Adventists, Denver, Colorado, United States

Born in Poland, Rajmund Dąbrowski, journalist, publisher, and corporate communication specialist, has been involved with Seventh-day Adventist Church's communication for over 45 years. Educated in England and the United States, his professional life included coordination of corporate communication of the church in Warsaw, Poland; the Trans-European Division in St. Albans, England; and as world church communication director, 1994-2010. He oversaw establishment of the Adventist News Network, and also coordinated the denomination's world communication strategy, including establishing the church's global corporate identity. He lives in Longmont, Colorado, with his wife, Grażyna, and holds the position of communication director of the Church's Rocky Mountain Conference in Denver Colorado. 


\section{DICLOSURE}

Author reports no conflict of interest.

\section{References}

1. Seventh-day Adventist Encyclopedia, p. 682 (Review and Herald Publishing Association, Hagerstown, MD, 21740, USA 1996).

2. Zatoński M, Stokłosa M. Report from the seminar on the past, present, and future of tobacco control, Harvard University Department of the History of Science. Cambridge, Massachusetts, October 2016. J Health Inequal 2017; 1: 16-23. 